[Agr. Biol. Chem., Vol. 34, No. 11, p. 1760 1761, 1970]

\title{
Isolation of New Chlorosis-inducing Substances Produced by Fungus
}

Sir:

To the best of our knowledge, there were only two reports that phytopathogenic fungi, Puccinia graminis ${ }^{11}$ and Alternaria tenuis, ${ }^{21}$ produced chlorosis-inducing substances, but the active principle is not isolated yet. We have found that the culture filtrate of the fungus No, 501-7Y (genus and species unidentified) induced chlorosis of plants, and isolated two active substances in crystalline state. We now wish to report the first instance of the isolation of chlorosis-inducing metabolites of fungus and their physicochemical properties and biological activities.

The fungus was shaken at $29^{\circ} \mathrm{C}$ for 6 days in a natural medium containing peptone and corn steep liquor. The culture filtrate was acidified with sulfuric acid to $\mathrm{pH} 3$, and extracted with ethyl acetate. The extract was fractionated into strongly acidic and weakly acidic-neutral fraction. The former was analysed by thin-layer chromatography (silicic acid developed in chloroform/ethanol $8: 1$ ) and the active components were located at $R f 0.35$ and 0.50 . By repeated chromatography with a column of silica gel (benzene/ethanol and chloroform ethanol) of the strongly acidic fraction, one active component ( $R f$ 0.50) was isolated as colorless powder and the other $(R f$ 0.35 ) as colorless needle (acetone-hexane, mp $\left.168 \sim 171^{\circ} \mathrm{C}\right)$. We proposed the name "viridominic acids' $A$ and $C$ (VA-A and $-\mathrm{C}$ ) for these compounds, respectively.

$\mathrm{VA}-\mathrm{A}$ and $-\mathrm{C}$ are carboxylic acid and were

1) W. Silverman, Phytopathology, 50, 130 (1960).

2) G. E. Templeton, C. I. Grable, N. D. Fulton and K. Bollenbacher, Phytochemistry, 57, 516 (1967). methylated with diazomethane in ether to give monomethyl ester, VA-A methyl ester: $\mathrm{mp} 110 \sim 112^{\circ} \mathrm{C}$ (acetone-hexane) and VA-C methyl ester: $\mathrm{mp} 186.5 \sim 187.5^{\circ} \mathrm{C}$ (ether-hexane). These compounds are optically active and the infrared (Fig. 1) and ultraviolet spectra are

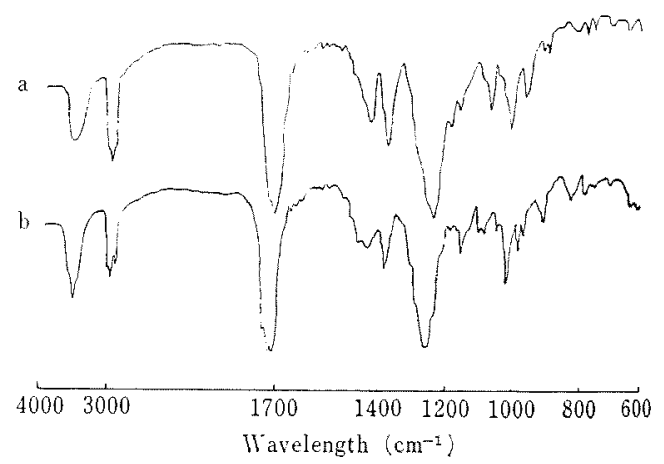

FIG. 1. Infrared Spectra of Viridominic Acids A and $\mathrm{C}$ ( $\mathrm{KBr}$ disk).

$a$, viridominic acid $A ; b$, viridominic acid $C$.

almost superimporsable, VA-V methyl ester: $[\alpha]_{D}^{25}+23^{\circ} \quad(c=0.1, \mathrm{MeOH}), \quad \nu_{\mathrm{max}}^{\mathrm{K} \mathrm{Br}} \mathrm{cm}^{-1}: 3500$, 1710 (br.), 1245, 1020 and 900, $\lambda_{\max }^{\mathrm{EtOH}} \mathrm{m} \mu(\varepsilon): 217$ $(8,100)$, VA-G methyl ester: $[\alpha]_{D}^{25}+42^{\circ}(c=0.1$, $\mathrm{MeOH}), \quad \nu_{\max }^{\mathrm{KBr}} \mathrm{cm}^{-1} . \quad 3450, \quad 1715$ (br.), 1216, 1017 and $915, \lambda_{\max }^{\mathrm{EtOH}} \mathrm{m} \mu(s): 216(10,100)$. The molecular formula of VA-A methyl ester, $\mathrm{C}_{34} \mathrm{H}_{50} \mathrm{O}_{9}$, and VA-C methyl ester, $\mathrm{C}_{34} \mathrm{H}_{52} \mathrm{O}_{9}$, were determined by high resolution mass spectrometries and elemental analyses, VA-A methyl ester: m/e $510.3022\left(\mathrm{M}^{+}-60-32\right)$, Calcd. for $\mathrm{C}_{31} \mathrm{H}_{42} \mathrm{O}_{6}: 510.2981$, Anal. Found: C, 67.67; $\mathrm{H}, 8.54 \%$, Calcd. for $\mathrm{C}_{34} \mathrm{H}_{50} \mathrm{O}_{9}: \mathrm{C}, 67.75 ; \mathrm{H}$, 8.36\%. VA-C: m/e 530.3306 (M $\left.{ }^{+}-60\right)$, Calcd. for $\mathrm{C}_{31} \mathrm{H}_{46} \mathrm{O}_{7}: 530.3244$, methyl ester. Anal. Found: 
Table I. EFfect of VA-A, - C AND CCC on the Chlorophyll Synthesis in the Cotyledons of 7 DAys Old SeEdlings

Brassica campestris L.

\begin{tabular}{|c|c|c|c|c|c|c|}
\hline \multirow{2}{*}{ Treatment (ppm) } & \multirow{2}{*}{$\begin{array}{l}\text { Water } \\
\text { dist. }\end{array}$} & \multicolumn{2}{|c|}{ VA-A } & \multicolumn{2}{|c|}{ VA-C } & \multirow{2}{*}{$\begin{array}{c}\mathrm{CCC} \\
1,000\end{array}$} \\
\hline & & 1.0 & 10.0 & 100 & 500 & \\
\hline $\begin{array}{l}\text { Chlorophyll } a+b \\
\text { (mg/g fresh weight) }\end{array}$ & 1.25 & 0.145 & 0.0135 & 0.762 & 0.236 & 0.906 \\
\hline \multicolumn{7}{|l|}{ Panicum Crus-galli L. } \\
\hline \multirow{2}{*}{ Treatment (ppm) } & Water & \multicolumn{2}{|c|}{$\mathrm{VA}-\mathrm{A}$} & $\mathrm{CCC}$ & & \\
\hline & dist. & 5.0 & 25.0 & 1,000 & & \\
\hline $\begin{array}{l}\text { Chlorophyll } a+b \\
\text { (mg/g fresh weight) }\end{array}$ & 1.43 & 0.953 & 0.125 & 0.918 & & \\
\hline
\end{tabular}

Seeds of Chinese' cabbage (Brassica campestris L. var. pekinensis) or barnyard grass (Panicum Cruswgalli L. var. frumentaceum Trin.) were placed in Petri dishes on filter paper wetted with distilled water or solutions of the compounds to be tested, and incubated for 7 days in continuous fluorescent light at $28^{\circ} \mathrm{C}$. Chlorophyll content was determined by the method of $\mathbf{j}$. Bruinsma. ${ }^{3 !}$

C, 67.89; $\mathrm{H}, 8.680^{\circ}$, Calcd. for $\mathrm{C}_{34} \mathrm{H}_{52} \mathrm{O}_{9}: \mathrm{C}$, $67.52 ; \mathrm{H}, 8.67 \%$.

The cotyledons of Chinese, cabbage (Brassica campestris L. var. pekinensis) seedling treated with VA-A and -C were yellow or pale green but these compounds had no effect on the growth of these plants at the tested concentrations for ten days. The content of chlorophyll in the cotyledons was reduced $80 \sim 90 \%$ at the concentrations of $1 \mathrm{ppm}$ and $500 \mathrm{ppm}$ by VA-A and $-\mathrm{C}$, respectively (Table I). VA-A also reduced the content of chlorophyll in the coleoptiles and the leaves of barnyard grass (Panicum Crus-galli L. var. frumentaceum Trin.) seedling by about $90 \%$ at the concentration of $25 \mathrm{ppm}$ (Table I). (2-Ghloroethyl)trimethylammonium chloride (CCG), known as chlorosis-inducing substance, reduced the content of chlorophyll in the cotyledons of Chinese' cabbage and barnyard grass by about only $10 \%$ at the concentration of $1000 \mathrm{ppm}$ (Table I). Chlorosis induced by VA-A and $-\mathrm{C}$ was not reversed by the addition of magnesium or iron ions and also by the treatment with gibberellic acid, kinetin and pottassium ion which was known to reverse the chlorosis

3) J. Bruinsma, Photochem. and Photobiol., 2, 241 (1963). induced by some retardants and coumarin. ${ }^{4}$

As naturally occuring chlorosis-inducing substances, some antibiotics produced by Actinomycetes, e.g. streptomycin, ${ }^{51}$ carbomycin, ${ }^{61}$ kanamycin ${ }^{71}$ elc. are known to induce chlorosis of some green algae. VA-A and -C are quite different from these compounds in their physicochemical and biological properties. VA-A and - $\mathrm{C}$ are new compounds having strong chlorosis activity.

We are indebted to Mr. A. Miyazaki of our laboratory and Dr, K. Fuji of Kyoto University for measurements of high resolution mass speatra.

Hirotsugu KaISE
Yasuo OGAWA
Takeshi SASSA
Katsura MUNAKATA

Department of Agricultural Chemistry, Nagoya University,

Nagoya, Japan

Received September 24, 1970

4) J.S. Knyple, Nature, 224, 1025 (1969).

5) L. Provasoli, S. H. Hutner and A. Schatz, Proc. Soc. Exptl. Biol. Med., 69, 279 (1948).

6) L. Ebriger, Folia Microbiol. (Prague), 11, 379 (1966).

7) L. Ebreger, J. Antibiotics (Japan), A15, 113 (1962). 